${ }^{1}$ Doctor of Technical Sciences, Professor, Pro-rector on scientific and pedagogical work and questions of prospects for the development of the university Zaporizhzhye National Technical University, Zaporizhzhya, Ukraine ${ }^{2}$ Ph.D. Associate Professor of Radioengineering and Telecommunication Department, Zaporizhzhye National Technical University, Zaporizhzhya, Ukraine

${ }^{3}$ Ph.D, Head of the department State Enterprise "Scientific and production complex "Iskra", Zaporizhzhya, Ukraine ${ }^{4}$ Head of the division State Enterprise "Scientific and production complex "Iskra", Zaporizhzhya, Ukraine

\title{
SELECTOR OF CLASSIFIED TRAINING SAMPLES FOR SPATIAL PROCESSING OF SIGNALS UNDER THE IMPACT OF COMBINED CLUTTER AND JAMMING
}

Context. In the conditions of combined clutter and jamming radar performance is significantly degraded. This is due to the decorrelation of a point source of an active jamming by spatially distributed passive clutter. The methods of forming classified training samples to adjust the weight coefficients of spatial filters are introduced.

Objective. The goal is developing an effective method of forming of classified training samples generated by an active masking jamming, for spatial processing of radar signals in a situation of the clutter influence.

Methods. The scientific novelty of this work is in developing a new method of forming the training samples based on the estimation of the width of the normalized autocorrelation function in each range resolution element. On-the-fly analysis of the components of combined clutter and jamming in each range resolution element improves the quality of the components classification and, as a result, minimizes the effect of passive clutter on a spatial filter adaptation process.

Results. The theoretical and practical aspects of the forming of the classified training samples are analyzed. A functional flow block diagram of the classifier of combined clutter components was developed.

Conclusions. Using of the on-the-fly analysis of the combined clutter and jamming components in each range resolution element improves the quality of the clutter classification, which is important in complex hydrometeorological conditions.

Keywords: radar signals processing, adaptive spatial filtering, combined clutter and jamming, classified training samples, normalized autocorrelation function, functional flow block diagram.

\section{NOMENCLATURE}

$\mathrm{ACF}$ - autocorrelation function;

ADC - analog to digital converter;

$\mathrm{D}$ - divisor;

COMP - comparator;

AA - adder-accumulator;

DR - delay register;

$B(\tau)$ - correlation function of a random process;

$c$ - speed of the electromagnetic wave;

$\Delta D$ - range resolution of the radar;

$i$ - sample number of the received signal;

$k$ - number of the phase channel;

$N$ - number of Fourier transformation points;

$n$ - number of repetition period;

$p$ - variable for signal delay;

$R_{1}$ - normalized autocorrelation function of active jamming;

$R_{2}$ - normalized autocorrelation function of passive clutter;

$R(p)$ - signal autocorrelation function, normalized to its power, in each element of range resolution;

$[0, t]$ - interval of forming weight coefficient;

$U_{i}$ - jamming amplitude in $i$-sample;

$\tau$ - time of signal delay while calculating the ACF;

$\dot{U}_{0}-$ complex value of the signal at the main input of the spatial filter;

$\dot{U}_{\Sigma}-$ complex value of the signal at the output of the spatial filter;

$\dot{U}_{k}$ - complex value of the signal at the input of the compensation channel;
$\dot{W}$ - complex value of the weight coefficient;

$\dot{W}_{0}$ - initial complex value of the weight coefficient;

$\dot{W}_{i+1}$ - current complex value of the weight coefficient;

$W(\omega)$ - energy spectrum of a random process;

$\dot{X}_{i}(n)$ - complex value of the signal amplitude at the $i$-th time in the $n$-th repetition period;

$\dot{X}(k)$ - complex value of the signal at the output of the $k$-th phase filter;

$|\dot{\rho}|$ - absolute value of the normalized inter-channel correlation coefficient.

\section{INTRODUCTION}

The most difficult conditions for a radar system operation are the simultaneous effect of active jamming and passive clutter. As it is known, active masking jamming may have of natural or artificial origin [1]. However, regardless of its origin, it is a point source. Passive clutter is the result in of reflections of the probing signal from the hydrometeors, dipole clouds, and underlying surface [2]. Spatially distributed nature of clutter degrades the spatial correlation for point sources of active masking jamming [3]. This leads to a significant deterioration in the quality of its compensation.

Information on the spatial distribution of hydrometeors in range and altitude of their location from the [4], gives possibility to assume that the signals reflected from them are non-stationary in time. Non-stationary are also the signals reflected by the underlying surface and chaff clouds [6]. The dimensions of the cloud of one chaff batch in the

(C) Piza D. M., Bugrova T. I., Lavrentiev V. M., Semenov D. S., 2017

DOI 10.15588/1607-3274-2017-4-3 
vertical (horizontal) plane are $0.6 \ldots 1 \mathrm{~km}$ in $5 \mathrm{~min}$ after the throw and $1.6 \ldots 2 \mathrm{~km}$ in $10 \mathrm{~min}$ after the throw [2]. Therefore, we can assume that, taking into consideration real spatial distribution of passive clutter, on the scanning range it is possible to find time intervals to form the classified training samples which related to the active masking jamming [5]. Using classified training samples in spatial signal processing enhances the efficiency of signal processing under the impact of combined clutter that determines the relevance of the topic of this article.

The goal is developing an effective method of forming of classified training samples generated by an active masking jamming, for spatial processing of radar signals in a situation of the clutter influence.

\section{PROBLEM STATEMENT}

Optimal signal processing in the conditions of combined interference with the using of adaptive antenna arrays can be provided by joint (non-separable) space-time processing with simultaneous compensation of active (jamming) and passive (clutter) interference. However, its implementation even on the modern element base is extremely difficult [5]. Therefore, during designing modern samples of radar stations, it is necessary to use a separate two-stage signal processing procedure. Possible realizations are space-time or time-space signal processing [6]. In this case, the well-known autocompensators of the interference are used as the adaptation element of the spatial filter [1]. It was noted in [5] that, from the point of view of the possibility of obtaining the classified training samples, spatio-temporal (space-time) processing is preferable. Therefore, we can clarify the problem that will be solved in this article and formulate it as follows. It is necessary to review the existing methods of forming the classified training samples for adapting the weight coefficients of the auto-compensator of interference while spatio-temporal (space-time) signal processing and the structure optimization of the interference classifier.

The main problem to be solved in this work is the development of a new method for classifying the components of the combined interference, which ensures their classification in each element of the range resolution.

\section{LITERATURE REWIEW}

When the two-stage space-time signal processing is doing in separated way, the jamming acting on the side lobes of the antenna pattern is compensated firstly by adjusting the weight coefficients of the auto-compensator. Then spectral analysis of signals is performed (DFT based) as temporal processing in modern radar systems:

$$
\dot{X}(k)=\sum_{n=0}^{N-1} a_{n} \dot{X}_{i}(n) \exp \left\{j \frac{2 \pi n k}{N}\right\} .
$$

Further we will assume that the number of probing pulses in the emitted pulses sequence is equal to the number of points of the Fourier transform. An example is an American ASR-9 radar with a number of filter channels, depending on the pulse repetition frequency, equal to 8 or 10 [7], or the Ukrainian radar station 36D6 [8], in which 8, 12 or 16 filter channels are realized.

A simplified block diagram of the space-time processing is shown on Fig. 1.

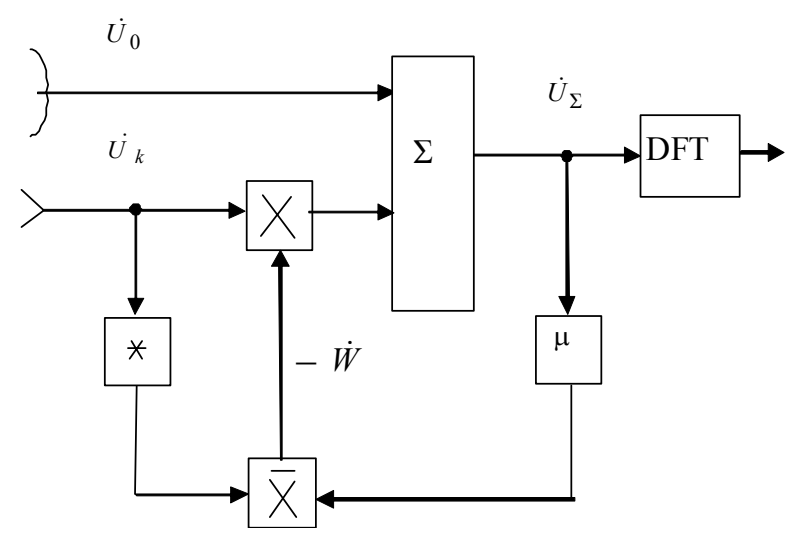

Figure 1 - Simplified block diagram of space-time processing

In accordance with this block diagram, the complex value of the interference at the output of the spatial filter can be written in the following form:

$$
\dot{U}_{\Sigma_{i}}=\dot{U}_{0_{i}}-\dot{W}_{i} \dot{U}_{k_{i}}
$$

In this case, the complex value of the weight coefficient $\dot{W}$ in the circuit using the classical Widrow algorithm [9] is defined as

$$
\dot{W}_{i+1}=\dot{W}_{i}-2 \mu \dot{U}_{k_{i}}^{*} \dot{U}_{\Sigma_{i}}
$$

or

$$
\dot{W}(t)=2 \mu \int_{0}^{t_{\phi}} \dot{U}_{k}^{*}(t) \dot{U}_{\Sigma}(t) d t+\dot{W}_{0} .
$$

In [10], it was proposed to use the time interval which corresponded to the end of the radar range to form the classified training samples when adaptation of the weight coefficients of the auto-compensator of the interference. The duration of the interval $t$ in the expression (4) when forming the weight coefficients is determined by the speed of the auto-compensator for the interference. The proposed technical solution was based on the assumption that the intensity of passive interference decreases substantially with increasing distance. However, in an experiment conducted in polygon conditions, it was determined that for spatially distributed cloud systems of the Cb type [4], the intensity of passive interference, even at the maximum range, can significantly exceed the noise level of the receiving parts of the radar station. It does not let ensure effective compensation of the active component of the combined interference.

In patents $[11,12]$ the methods of forming the training samples with real non-stationary nature of clutter in range are introduced. The methods proposed in the patents are based on the posteriori information on the distribution of the passive component of the combined clutter in range. When active jamming and passive clutter act simultaneously, the latter decorrelates the signals from a point source of active clutter. Therefore, in the proposed methods current estimation of the distribution of a normalized coefficient of the inter-channel correlation in range is carried out. In this case it is possible to select the time interval for the forming of the classified training samples with the maximum value of 
the correlation coefficient, which corresponds to the lowest level (or eliminated) of passive clutter.

Absolute value of the normalized inter-channel correlation coefficient $|\dot{\rho}|$ can be calculated by the method of "sliding window" at intervals which has of $m$ range elements

$$
|\dot{\rho}|=\frac{\overline{\mid \dot{U}_{0}} \dot{U}_{k}^{*} \mid}{\sqrt{\left|\dot{U}_{0}\right|^{2}} \overline{\left|\dot{U}_{k}\right|^{2}}} .
$$

The number of range elements subject to averaging in the expression (5) is determined by the time of adaptation weight coefficients in a spatial filter.

In the patent [11] with calculating by the expression (5), the value of the normalized coefficient of inter-channel correlation is processed in the threshold device. In this case, if the calculated value of the current distance interval exceeds a threshold, that is corresponds to "no passive clutter", this interval is used as the classified training samples while adapting a spatial filter.

The disadvantage of this method is the use of a threshold device, which does not allow considering in detail the distribution of a normalized correlation coefficient in range, for example, for determining the time interval with a maximum value of the inter-channel correlation.

The patent [12] proposes a method, which provides a more detailed analysis of the distribution of an inter-channel correlation coefficient in range, which is the following. Values calculated by the expression (5) are stored, and at the end of the probe pulse repetition period by comparing all calculated values in the interval with a maximum value of the normalized inter-channel correlation coefficient is determined. In the next repetition period in a given interval the classified training samples for the adaptation of weight coefficients of a spatial filter is formed.

The common disadvantage of both methods is a certain probability of presence in $\mathrm{m}$ averaging intervals of some range elements exposed to passive clutter, which defines the limit the possibilities of classification. Therefore, to improve the quality of the clutter classification it is interesting to develop a method for estimation the possible impact of passive clutter on the forming of the classified training samples in each range resolution element.

\section{MATERIALS AND METHODS}

There is a theorem of Wiener-Khinchin [13], asserting that a correlation function of a random process $B(\tau)$ and an energy spectrum $W(\varpi)$ are interconnected by the Fourier transform:

$$
\begin{aligned}
& B(\tau)=\frac{1}{2 \pi} \int_{-\infty}^{\infty} \mathrm{W}(\varpi) e^{j \varpi \tau} d \omega, \\
& W(\varpi)=\int_{-\infty}^{\infty} \mathrm{B}(\tau) e^{j \varpi \tau} d \tau .
\end{aligned}
$$

This follows from expressions (6) and (7) that the wider an energy spectrum of a random process is, the shorter is a correlation interval and, accordingly, the more a correlation interval is, the narrower is an energy spectrum of the process.

Given that the correlation function of passive clutter is wider than active noise jamming, it is possible to determine the moment of exposure to passive clutter by the value of the correlation interval.

In Fig. 2 curves $R_{1}$ and $R_{2}$ show normalized autocorrelation functions (ACF) of active jamming and passive clutter at ratio of the spectral width of five to one, respectively.

A possible solution to this problem can be achieved by the on-the-fly calculation and estimation of the width of the normalized autocorrelation function of combined clutter in each interval $\Delta \mathrm{D}$, which determines the range resolution of the radar:

$$
\Delta \mathrm{D}=\frac{c}{2} \tau_{i}
$$

where $c$ is the speed of the electromagnetic wave, $\tau_{i}-$ the duration of the probe pulse.

The essence of the proposed method of forming the classified training samples is following. Taking into consideration a sufficiently bigger processing productivity of the existing electronic components, it is possible to form $n$ received signal samples in the interval, which determines the range resolution of the radar $\Delta \mathrm{D}$. This allows to

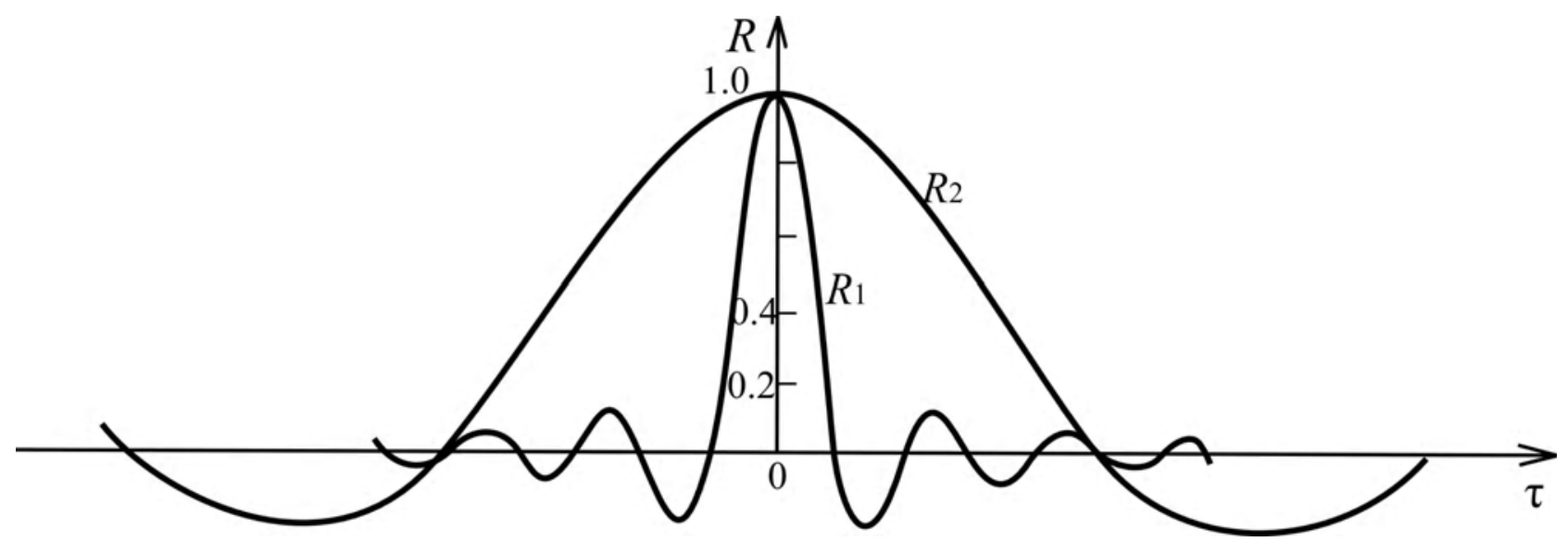

Figure 2 - Normalized ACF of active jamming $R_{1}$ and passive clutter $R_{2}$ 
calculate the signal autocorrelation function $R(p)$, which normalized to its power [14], in each element of range resolution.

$$
R(p)=\sum_{i=1}^{n} U_{i} U_{i+p} / \sum_{i}^{n} U_{i}^{2} .
$$

where $i-$ the sequenced number of the received signal sample, $n$ - the number of them, $U_{i}$ - the signal amplitude in $i$ - samples, $p$ - variable determining a signal delay in the forming of ACF $(p=1, \ldots, n)$. Wherein the time of signal delay $\phi$ while calculating the ACF is equal to:

$$
\tau=p \frac{\tau_{i}}{n}
$$

In the future, by comparing the width of the ACF to a threshold the range resolution elements affected by passive clutter are detected and excluded while forming the training samples. This makes it possible to create the classified training samples generated by active clutter only, and be ensured in high quality of the compensation of the latter.

\section{EXPERIMENTS}

A functional flow block diagram of the device that implements the proposed method of forming the training samples is shown in Fig. 3.

For calculating the ACF the envelope of the signal is demodulated, then in each range resolution element the analog to digital converter ADC forms n samples, which, in accordance with formula (10) are delayed in delay registers $D R_{1} \ldots D R_{n}$ and then supplied to the first inputs of the multipliers $\mathrm{X}$. To the second inputs of $\mathrm{n}$ multipliers $\mathrm{X}$ the respective nondelayed samples get directly from the ADC. On the outputs of $n$ multipliers $\mathrm{X} n$ products of the numerator of the expression (9) are formed, they accumulate in respective adder-accumulators AA and are fed to first inputs of $\mathrm{n}$ divisors $\mathrm{D}$ (as a dividend). The signals from the output of the ADC also supplied to both inputs of $(n+1)$-th multiplier. Squared signal samples in accordance with expression (9) are accumulated in adder $A A_{n+1}$ and supplied to the second inputs of $n$ divisors D. As a result, on the outputs of $n$ divisors D ACF values of the received signal, normalized according to power (9) will be formed, wherein each calculated value of ACF corresponds to its delay time (10).

The calculated values of the ACF get to $n$ inputs of the ACF width calculating block, where by means of comparison the sequence number of the $p_{k}$ divider is determined, on the output of which the normalized correlation function is close to some fixed level, e.g., 0.5. Estimated in this way the width of the ACF $\left(p_{k}{ }^{*} \tau_{i} / n\right)$ is supplied to the comparator COMP. The value of the threshold is set so that the probability of exceeding it under the influence of active jamming were small enough. When the threshold is exceeded it is determined that in the given range $\Delta \mathrm{D}(8)$, equal to the range resolution element, there is passive clutter. At the same time, on the output of the comparator COMP a logic level, prohibiting the use of this interval to forming the classified training samples is generated.

A significant advantage of the proposed method is the possibility of obtaining the classified training samples of maximum duration. This is achieved by the analysis of the components of combined clutter in each range resolution element.

\section{RESULTS}

As a result of the research, a new method of forming the classified training samples using a posteriori information was proposed to form the weight coefficients of the adaptive spatial or polarization filters under conditions of the combined clutter and jamming.

In the known correlation method [12], a posteriori information is used on the current estimation of the distribution of the normalized inter-channel correlation coefficient at range intervals. In this method, range intervals

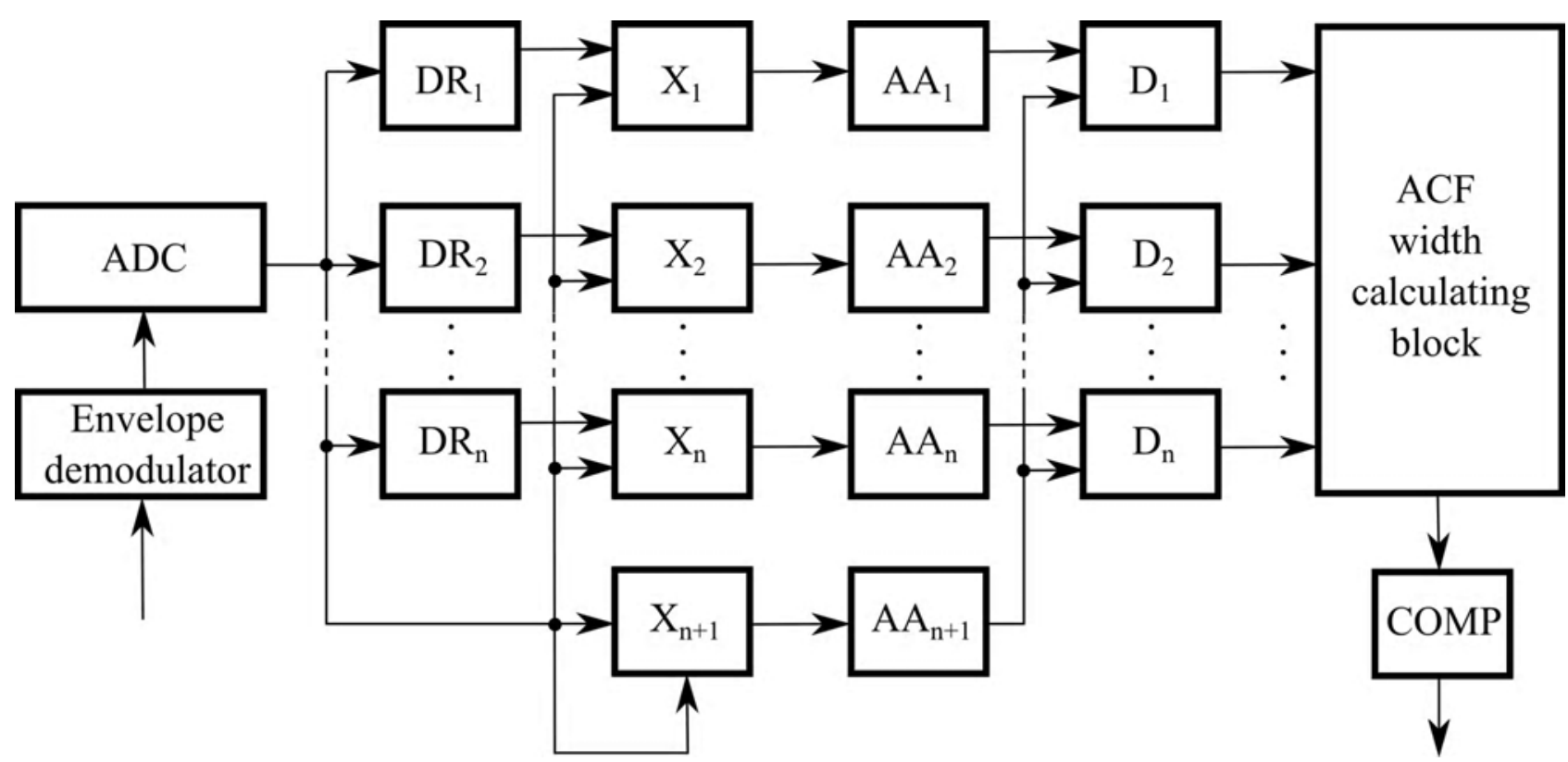

Figure 3 - Functional flow block diagram of the device for the forming of the training samples 
at which passive interference decorrelates the active noise interference are eliminated from the forming of the training samples. However it is impossible to obtain a time interval of sufficient duration for forming the classified training samples in the lower beams of the radar in complex hydrometeorological conditions and intensive reflections from the underlying surface.

It is possible to classify the components of the combined interference in the proposed method by forming a set of samples in an interval equal to the resolution element, followed by averaging in calculating the width of the normalized ACF. In this case, each resolution element in which there is no passive interference (clutter) can be used to form the classified training samples for generating the weight coefficients of the adaptive filters for suppressing the active component of the combined interference.

\section{DISCUSSION}

Figure 4 shows energy "azimuth-range portraits" of reflections obtained in the lower beam of the S-band radar 36D6, which are taken from article [15]. In the near part of the range (up to 100 kilometers) clutter is formed by rereflections from the underlying surface of the earth. Their intensity reaches $50-60 \mathrm{~dB}$. In the middle part of the range (100-150 kilometers) clutter is formed by reflections from rain clouds. It is shown in [16] (by modeling), the compensation of the jamming becomes problematic if the level of jamming is less then level of clutter.

An analysis of the given energy characteristics shows that even in the lower beam of the directivity pattern of the antenna at the range coordinate there are small intervals at which clutter is absent or have a much lower intensity. It is obviously, the proposed method makes it possible to generate the classified training samples generated by an active noise interference by using samples from resolution elements, where there is no clutter.

\section{CONCLUSIONS}

1. The scientific novelty of this work is in the development of a new method of forming the training samples, based on the estimation of the width of a normalized autocorrelation function in each range resolution element. On-the-fly analysis of the components of combined clutter and jamming in each resolution element improves the quality of

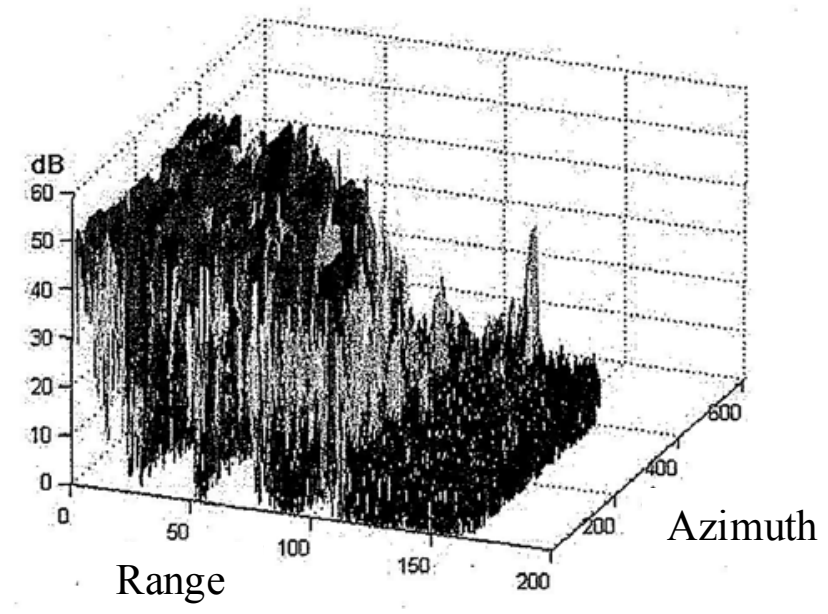

Figure 4 - Azimuth-range portraits of clutters for 36D6 radar classification of clutter components and, as a result, minimizes the effect of passive clutter on spatial filter adaptation process.

2. The advantage of the proposed method is also the possibility of obtaining the classified training samples with maximum duration. It is achieved by the analysis of the components of combined clutter and jamming in each range resolution element.

3. The practical novelty is in the development of a functional flow block diagram realizing the proposed method.

\section{ACKNOWLEDGEMENTS}

The paper was conducted within the framework of research project "Development and improvement of signal processing algorithms in radio engineering and telecommunication systems" (№0117U000013T) at Zaporizhzhye National Technical University with the financial support of the Ministry of Education and Science of Ukraine.

\section{REFERENCES}

1. Теоретические основы радиолокации : учеб. пособие для вузов / [Я. Д. Ширман, В. Н. Голиков, И. Н. Бусыгин и др.] ; под общ. ред. Я. Д. Ширмана. М. : Сов. радио, 1970. - 560 с.

2. Радиоэлектронные системы: Основы построения и теория. Справочник. Изд. 2-е, перераб. и доп. / Под ред. Я. Д. Ширмана. - М. : Радиотехника, 2007. - 512 с.

3. Журавльов А. К. Адаптивные радиотехнические системы с антенными решетками / А. К. Журавльов, В. А. Хлебников и др. - Л. : Изд. Ленинградского университета, 1991. - 544 с.

4. Атлас облаков / Федер. Служба по гидрометеорологии и мониторингу окружающей среды (Росгидромет), Гл. геофиз. обсерватория им. А.И. Воейкова; [Д.П. Беспалов и др.; ред.: Л. К. Сурыгина]. - Санкт-Петербург : Д’АРТ, 2011. - 248 с.

5. Оценка интервала фиксации пространственного весового вектора при последовательной пространственно-временной обработке сигналов на фоне комбинированных помех / [В. П. Рябуха, Д. С. Рачков, А. В. Семеняка, Е. А. Катюшин] // Известия высших учебных заведений. Радиоэлектроника. 2012. - № 10. - С. 13-25.

6. Залевский А. П. Оценка эффективности пространственно-временной и время-пространственной фильтрации сигналов в когерентно-импульсных РЛС / [А. П. Залевский, Д. М. Пиза, И. С. Пресняк, А. С. Сиренко] // Радиоэлектроника, информатика, управление. - 2012. - № 2. - C. 39-44. DOI: http// dx.doi.org/10.15588/1604-3274-2012-7.

7. Тейлор Дж.У. Новая диспетчерская PЛC ASR-9 / Дж.У. Тейлор, Г. Бруникс // ТИИЭР. - 1985. - Т. 73, № 2. С. 284-289.

8. Радиолокационная станция 36Д6М. Эксплуатация и техническое обслуживание [Текст] : учеб. пособие / [И. Д. Май, А. Г. Каспирович, В. А. Винник и др.] - Запорожье : КП «НПК «Искра». - 140 с.

9. Уидроу Б. Адаптивная обработка сигналов : пер. с англ. / Б. Уидроу, С. Стирнз. - М. : Радио и связь, 1989. - 440 с.

10. Пат. 48705 Україна, МПК G01 S 7/36 H04B 15/00. Спосіб компенсації активної складової комбінованої завади / Кононович В. Я., Кукольницький А. П., Залевський О. П., Каспирович О. Г.; Майстер Ю. Л., Денека А. А. ; Казенне підприємство «Науково-виробничий комплекс «Іскра». № u200911296; Заявл. 2009.11.06; Опубл. 2010.03.25, Бюл. №6, 2010 р. - 4 c.

11. Пат. 59472 Україна, MKI G01S 7/3б. Спосіб захисту когерентно-імпульсної РЛС від комбінованих завад / Піза Д. М., Залевський О. П., Рудик О. В.; заявник та патентовласник Запо- 
різький національний технічний університет; заявл. 28.08.2011; опубл. 10.05.2011, Бюл. № 9 .

12. Пат. 78120 Україна, MПК G01S 7/36 Спосіб захисту когерентно-імпульсних радіолокаційних станцій від комбінованих завад / Піза Д. М., Сіренко А. С.; Запорізький національний технічний університет; заявл. 28.08.2012; опубл. 11.03.2013, Бюл. № 5.

13. Гоноровский И. С. Радиотехнические цепи и сигналы : учебник для вузов / И. С. Гоноровский. - М. : «Сов. радио», 1977. -608 с.

14. Рабинер Л. Теория и применение цифровой обработки сигналов / Л. Рабинер, Б. Гоулд. - М. : Мир, 1978. - 444 с.

15. Леховицкий Д. И. СДЦ в импульноых РЛС: 1. Физический смысл и экстремальные свойства операций оптимальной междупериодной обработки гауссовых сигналов на фоне гауссовых пассивных помех [Текст] / Д. И. Леховицкий, В. П. Рябуха, Г. А. Жуга // Прикладная радиоэлектроника. - 2011. Том 10, №4.

16. Пиза Д. М. Метод компенсации активной составляющей комбинированной помехи в когерентно-импульсной РЛС [Текст] / Д. М. Пиза, Е. А. Звягинцев, Г. В. Мороз // Известия высших учебных заведений. Радиоэлектроника. - 2016. - № 6. C. 23-29. DOI:10.20535/S0021347016060030

Article was submitted 19.06.2017. After revision 25.09.2017.

Піза Д. М. ${ }^{1}$, Бугрова Т. І. ${ }^{2}$, Лаврентьєв В. М. ${ }^{3}$, Семенов Д. С. ${ }^{4}$

${ }^{1}$ Д-р техн. наук, професор, проректор з науково-педагогічної роботи та питань перспектив розвиту університету, Запорізький національний технічний університет, Запоріжжя, Україна

${ }^{2}$ Канд. техн. наук, доцент кафедри Радіотехніки та телекомунікацій, Запорізький національний технічний університет, Запоріжжя, Україна

${ }^{3}$ Канд. техн. наук, начальник науково-дослідного відділу, Казенне підприємство «Науково-виробничий комплекс «Іскра», Запоріжжя, Україна

${ }^{4}$ Начальник відділу, Казенне підприємство «Науково-виробничий комплекс «Іскра», Запоріжжя, Україна

ФОРМУВАЧ КЛАСИФІКАЦЙНОЇ НАВЧАЛЬНОӤ ВИБІРКИ ПРИ ПРОСТОРОВІЙ ОБРОБЦІ РАДІОЛОКАЦІЙНИХ СИГНАЛІВ В УМОВАХ ДІЇ КОМБІНОВАНОЇ ЗАВАДИ

Актуальність. В умовах впливу комбінованих завад ефективність роботи радіолокаційних засобів істотно погіршується. Це обумовлено декореляцією точкового джерела активної завади просторово-розподіленим характером пасивної завади. Розглядаються методи формування класифікаційної навчальної вибірки для адаптації вагових коефіцієнтів просторових фільтрів.

Мета. Розробка ефективного методу формування класифікаційної навчальної вибірки, породженої активною маскуючою завадою, для просторової обробки радіолокаційних сигналів в умовах одночасного впливу пасивних завад.

Методи. Наукова новизна роботи полягає в розробці нового методу формування навчальної вибірки, заснованого на оцінці ширини нормованої автокореляційної функції в кожному елементі розділення по дальності. Поточний аналіз складових комбінованої завади в кожному елементі розділення підвищує якість класифікації складових завад i, як наслідок, мінімізує вплив пасивної завади на процес адаптації просторового фільтра.

Результати. Розглянуто теоретичні та практичні аспекти формування класифікаційної навчальної вибірки. Розроблено функціональну схему класифікатора складових комбінованої завади.

Висновки. Поточний аналіз складових комбінованої завади в кожному елементі розділення по дальності підвищує якість класифікації завад, що важливо в умовах складної гідрометеорологічної обстановки.

Ключові слова: обробка радіолокаційних сигналів, адаптивна просторова фільтрація, комбінована завада, класифікаційна навчальна вибірка, нормована автокореляційна функція, функціональна схема.

Пиза Д. М. ${ }^{1}$, Бугрова Т. И. ${ }^{2}$, Лаврентьев В. Н. ${ }^{3}$, Семенов Д. С. ${ }^{4}$

${ }^{1}$ Д-р техн. наук, профессор, Проректор по научно-педагогический работе и вопросам перспектив развития университета, Запорожский национальный технический университет, Запорожье, Украина

${ }^{2}$ Канд. техн. наук, доцент кафедры Радиотехники и телекоммуникаций, Запорожский национальный технический университет, Запорожье, Украина

${ }^{3}$ Канд. техн. наук, начальник научно-исследовательского отделения, Казенное предприятие «Научно-производственный комплекс «Искра», Запорожье, Украина

${ }^{4}$ Начальник отдела, Казенное предприятие «Научно-производственный комплекс «Искра», Запорожье, Украина

ФОРМИРОВАТЕЛЬ КЛАССИФИЦИРОВАННОЙ ОБУЧАЮЩЕЙ ВЫБОРКИ ПРИ ПРОСТРАНСТВЕННОЙ ОБРАБОТКЕ РАДИОЛОКАЦИОННЫХ СИГНАЛОВ В УСЛОВИЯХ ВОЗДЕЙСТВИЯ КОМБИНИРОВАННОЙ ПОМЕХИ

Актуальность. В условиях воздействия комбинированных помех эффективность работы радиолокационных средств существенно ухудшается. Это обусловлено декорреляцией точечного источника активной помехи пространственно-распределенным характером пассивной помехи. Рассматриваются методы формирования классифицированной обучающей выборки для адаптации весовых коэффициентов пространственных фильтров.

Цель. Разработка эффективного метода формирования классифицированной обучающей выборки, порожденной активной маскирующей помехой, для пространственной обработки радиолокационных сигналов в условиях одновременного воздействия пассивных помех.

Методы. Научная новизна работы состоит в разработке нового метода формирования обучающей выборки, основанного на оценке ширины нормированной автокорреляционной функции в каждом элементе разрешения по дальности. Текущий анализ составляющих комбинированной помехи в каждом элементе разрешения повышает качество классификации составляющих помех и, как следствие, минимизирует влияние пассивной помехи на процесс адаптации пространственного фильтра.

Результаты. Рассмотрены теоретические и практические аспекты формирования классифицированной обучающей выборки. Разработана функциональная схема классификатора составляющих комбинированной помехи.

Выводы. Текущий анализ составляющих комбинированной помехи в каждом элементе разрешения по дальности повышает качество классификации помех, что важно в условиях сложной гидрометеорологической обстановки. 
Ключевые слова: обработка радиолокационных сигналов, адаптивная пространственная фильтрация, комбинированная помеха, классифицированная обучающая выборка, нормированная автокорреляционная функция, функциональная схема.

\section{REFERENCES}

1. Shirman Ja. D., Golikov V. N., Busygin I. N. i dr.; pod obshh. red. Ja. D. Shirmana. Teoreticheskie osnovy radiolokacii: ucheb. posobie dlja vuzov. Moscow, Sov. radio, 1970, 560 p.

2. Radiojelektronnye sistemy: Osnovy postroenija i teorija. Spravochnik. Izd. 2-e, pererab. i dop.: Pod red. Ja. D. Shirmana. Moscow, Radiotehnika, 2007, 512 p.

3. Zhuravl'ov A. K., Hlebnikov V. A. i dr. Adaptivnye radiotehnicheskie sistemy s antennymi reshetkami. Leningrad, Izd. Leningradskogo universiteta, 1991, $544 \mathrm{p}$.

4. Bespalov D. P. i dr.; red.: Surygina L. K. Atlas oblakov Feder. Sluzhba po gidrometeorologii i monitoringu okruzhajushhej sredy (Ros-gidromet), Gl. geofiz. observatorija im. A. I. Voejkova. SanktPeterburg, D’ART, 2011, 248 p.

5. Rjabuha V. P., Rachkov D. S., Semenjaka A. V., Katjushin E. A. Ocenka intervala fiksacii prostran-stvennogo vesovogo vektora pri posledovatel'noj prostranstvenno-vremennoj obrabotke signalov na fone kombinirovannyh pomeh, Izvestija vysshih uchebnyh zavedenij. Radiojelektronika, 2012, No. 10, pp. 13-25.

6. Zalevskij A. P., Piza D. M. Presnjak I. S., Sirenko A. S. Ocenka jeffektivnosti prostranstvenno-vremennoj i vremjaprostranstvennoj fil'tracii signalov v kogerentno-impul'snyh RLS, Radio Electronics, Computer Science, Control, 2012, No. 2, pp. 39-44. DOI: http//dx.doi.org/10.15588/1604-32742012-7.

7. Tejlor Dzh.U., Bruniks G. Novaja dispetcherskaja RLS ASR-9 [Tekst], TIIJeR, 1985, Vol. 73, No. 2, pp. 284-289.

8. Maj I. D., Kaspirovich A. G., Vinnik V.A.i drRadiolokacionnaja stancija 36D6M. Jekspluatacija i tehnicheskoe obsluzhivanie [Tekst]: ucheb. posobie. Zaporozh'e, KP «NPK «Iskra», 140 p.
9. Uidrou B., Stirnz S. Adaptivnaja obrabotka signalov : per. s angl. Moscow, Radio i svjaz', 1989, 440 s.

10.Kononovich V. Ja., Kukol'nic'kij A. P., Zalevs'kij O. P., Kaspirovich O. G.; Majster Ju. L., Deneka A. A.; Pat. 48705 Ukraïna, MPK G01 S 7/36 H04B 15/00. Sposib kompensaciï aktivnoï skladovoï kombinovanoï zavadi [Tekst]. Kazenne pidpriєmstvo "Naukovo-virobnichij kompleks "Iskra". № u200911296; Zajavl. 2009.11.06; Opubl. 2010.03.25, Bjul. №6, $2010 \mathrm{r}, 4 \mathrm{p}$.

11. Piza D. M., Zalevs'kij O. P., Rudik O. V. Pat. 59472 Ukraïna, MKI G01S 7/3b. Sposib zahistu kogerentno-impul'snö̈ RLS vid kombinovanih zavad [Tekst]; zajavnik ta patentovlasnik. Zaporiz'kij nacional'nij tehnichnij universitet; zajavl. 28.08.2011; opubl. 10.05.2011, Bjul. № 9.

12. Piza D. M., Sirenko A. S.; Pat. 78120 Ukraïna, MPK G01S 7/36 Sposib zahistu kogerentno-impul'snih radiolokacijnih stancij vid kombinovanih zavad [Tekst]. Zaporiz'kij nacional'nij tehnichnij universitet; zajavl. 28.08.2012; opubl. 11.03.2013, Bjul. № 5 .

13. Gonorovskij I. S. Radiotehnicheskie cepi i signaly. Uchebnik dlja vuzov. Moscow, Sov. radio, 1977, 608 p.

14. Rabiner L., Gould B. Teorija i primenenie cifrovoj obrabotki signalov. Moscow, Mir, 1978, $444 \mathrm{p}$.

15. Lehovickij D. I., Rjabuha V. P., Zhuga G. A. SDC v impul'noyh RLS: 1. Fizicheskij smysl i jekstremal'nye svojstva operacij optimal'noj mezhduperiodnoj obrabotki gaussovyh signalov na fone gaussovyh passivnyh pomeh, Prikladnaja radiojelektronika, 2011, Tom 10 No. 4.

16. Piza D. M., Zvjagincev E. A., Moroz G. V. Metod kompensacii aktivnoj sostavljajushhej kombinirovannoj pomehi v kogerentnoimpul'snoj RLS [Tekst], Izvestija vysshih uchebnyh zavedenij. Radiojelektronika, 2016, No. 6, pp. 23-29. DOI:10.20535/ S0021347016060030 